\title{
TECHNICAL EFFICIENCY IN DAIRY FARMS CONDUCTING EDUCATIONAL TOURISM: AN APPROACH BY STOCHASTIC FRONTIER PRODUCTION FUNCTION
}

\author{
Y. OHE \\ Department of Food and Resource Economics, Chiba University, Japan.
}

\begin{abstract}
When farmers undertake a new activity such as tourism activity, it is crucial that they enlarge or redefine their identity from that of a simple farm producer to a farm resource manager with a wider perspective. This paper evaluates how a farmer's identity influences the efficiency of main activity, milk production by providing an emerging new educational tourism service. To approach this aim, based on an analytical framework, this paper classified farmer's identity into two types: traditional identity that is oriented towards simple farm production and enlarged identity that is oriented towards viability of the educational tourism activity. The estimation result of stochastic frontier production function (SFPF) revealed that, although conventional technical inefficiency is overestimated when the identity effect is not considered, the female initiative on the tourism activity enhances the technical efficiency of milk production. Consequently, it is when policymakers try to design support measures to develop tourismrelated farm diversification, the perspective of the support measures for capacity building should be widened to include identity issues.

Keywords: dairy farm, educational tourism in agriculture, identity, stochastic frontier production function, technical efficiency.
\end{abstract}

\section{INTRODUCTION}

Tourism conducted by farm people is now widely accepted as a measure of farm diversification that leads to rural revitalization and development not only in developed but also in developing countries. Within the arena of rural tourism, educational tourism in agriculture has been emerging and attracting growing attention because it is differentiated from ordinary rural tourism and allows the majority of visitors who do not have an agrarian background to learn more effectively of the significance of their rural heritage and the environment. Educational Dairy Farms (EDFs) are an organized framework of farms in Japan that provide educational services regarding agriculture, similar to other such highly organized activities conducted in other parts of the world. The number of visitors to these member farms increased to nearly 900,000 in 2009 , which strongly suggests that a new and potentially large market is emerging and that it should be explored as a new income source for farmers.

To realize tourism-oriented diversification, it is essential for farmers themselves to transform their identity as farm resource managers solely based on the traditional production-oriented perspective to a wider one based on a more comprehensive perspective of farm resource management that includes both traditional farm production and tourism activity. This is because the level of diversified farm activity that is undertaken by a farmer is not determined solely by the farmer's individual technical skills and capability, but by the farmer's identity that exists as a norm that is socially nurtured and has persisted for generations. In this context,

This paper is part of the Proceedings of the $7^{\text {th }}$ International Conference on Sustainable Tourism (Sustainable Tourism 2016)

www.witconferences.com 
even if farmers have sufficient capability to conduct diversified activities, those farmers with different identities will undertake specific activities in accordance with a particular identity and realize different degrees of technical efficiency. Identity factors have been only scantly empirically investigated among economic activities including agriculture, although Akerlof and Kranton [1] state their importance for a better understanding of economic behaviour.

To the author's knowledge, studies on factors related to inefficiency of production activity have been mainly conducted on their direct effect on production, which is exerted by factors within the same activity in tourism economics and agricultural economics. It has not been clarified yet how a diversified activity such as tourism undertaken by farmers with different identities results in different degrees of technical efficiency, including those related to a main activity such as milk production, hereafter the identity effect. If we could understand how identity exerts an influence on technical efficiency, we could expand the scope of farm diversification policies. It is crucially important to clarify this point in seeking a better perspective on the sustainable evolution of farm diversification through educational activity and in providing support measures for that.

Thus, it is necessary to consider not only the conventional technical reasons that cause production inefficiency but also the effect of a farmer's identity when we consider farm diversification in relation to the newly emerging tourism activity. Put differently, it is highly probable that observed technical efficiency includes the mixed effects of conventional technical inefficiency and the identity effect. If the identity effect is not taken into account, the technical efficiency of EDFs will be overestimated.

To approach this aim, by focusing on the designated EDFs in Japan, first this paper presents an analytical framework that enables us to evaluate how the activity of educational services exerts influence on the efficiency of the main activity, milk production, by the estimation of the stochastic frontier production function (SFPF). Finally, this paper presents policy recommendations towards the establishment of economically viable educational services.

\section{LITERATURE REVIEW}

Economic approaches to identity issues were firstly explored fully by Akerlof and Kranton [1-3]. Akerlof and Kranton [2] defined identity as a person's sense of self and proposed the utility function that identity is associated with different social categories and how people in these categories should behave. Akerlof and Kranton [3] investigated the connections between school and work. Akerlof and Kranton [1] also considered gender and race issues in connection with work and minority poverty. Further, Akerlof [4] dealt with the relationship between norms and macroeconomics. From a conceptual viewpoint, Sen [5] noted the significance of commitment observed in groups such as class and community and Sen [6] also mentioned that identity is associated with rule-based conduct. Sen [7] discussed that norms and identity will mitigate violence. Bowles [8] focused on endogenous preferences, such as motivation and values, influenced by economic institutions. Empirically, however, agriculture and tourism have not been explicitly studied in relation to identity issues.

As empirical methodology, SFPF is well recognized in the evaluation of efficiency and productivity [9]. SFPF models were proposed by Aigner et al. [10]. Anderson et al. [11] employed a stochastic frontier approach to the hotel industry. Gragasin et al. [12] applied the stochastic frontier function to evaluate farm productivity in a comparative study of two Philippine irrigation systems. Assaf et al. [13] investigated the cost efficiency of hotels by the Bayesian stochastic frontier model. Adhikari and Bjorndal [14] employed DEA and the stochastic distance function to Nepalese agriculture. Ohe [15] evaluated the productivity of rural tourism activities in Japan, but the stochastic frontier function have not been applied yet. Educational 
tourism in agriculture has not been extensively explored except for reports by Ohe [15-17], which mainly dealt with internalization of the educational externality generated by dairy farming, not directly with the identity aspect of farmers. To summarize, to my knowledge, there has not been an exploration of identity and an evaluation of efficiency by using SFPF with regard to farm diversification and rural tourism. It is for this reason that I conducted this study.

\section{ANALYTICAL FRAMEWORK: FARMERS' IDENTITY AND TECHNICAL EFFICIENCY}

Here, the researcher considers the relationship between a farmer's identity and the efficiency of diversified activity, that is, milk production and the educational activity. To simplify the discussion, suppose there are two contrasting types of identity that a farmer could have: traditional identity and enlarged identity. For those with the traditional identity, the norm is that their main activity is farm production, so that the educational service is just a voluntary activity offered free of charge. Thus, their aim is to realize efficient milk production to the best possible extent. On the other hand, in those with the enlarged identity, the norm is that they should engage in multiple economically viable activities and therefore they will levy service charges for the educational service to achieve its viability. Their aim is, thus, to attain technical efficiency in farm resource allocation among these activities, meaning that those with the enlarged identity have a wider perspective towards farm diversification than those with the traditional identity. In this respect, whether a farmer levies a service charge is an easily observable criterion to indicate which identity a farmer has.

Although identity can change with time, once it is established, in general, it is hard to change, and it can be passed down through generations. Even if a policy framework promotes farm diversification, efficient farm management will not be achieved unless a farmer's identity changes towards the enlarged one. Although this does not mean that those who conduct diversified activities as a volunteer do not engage in efficient farm resource management, those with the enlarged identity regard farm resource management more as economic behaviour than those with the traditional identity. Within each identity, the clearer the identity a farmer possesses, whether it is the traditional identity or the enlarged identity, the better able that farmer is to perform farm resource management. On the other hand, the farmer cannot realize efficient farm resource management if the activity is conducted beyond the scope of that farmer's own identity.

This process is not always undertaken consciously by farmers, which is different from regular inputs. The hypothesis here to be empirically examined is whether a farmer takes different maximization behaviours according to identity; in the case of traditional identity, one-sector efficiency maximization is taken, and in the case of enlarged identity, the maximization of overall managerial efficiency composed of milk production and the educational service, is taken.

Based on the above consideration, I explore the inter-activity effect (cross effect) between a diversified activity, such as an educational activity, and the main activity of milk production taking into account the identity aspect. It is considered as that the identity effect works similar to a technical bias on efficiency. In reality, the identity effect is likely to be combined with conventional technical factors that affect efficiency. The next question to be empirically clarified is to identify how managerial efficiency is attained when the identity effect is considered.

\section{OUTLINE OF THE PROGRAM OF THE EDUCATIONAL DAIRY FARMS}

The program of the EDFs was established in 2000 by the Japan Dairy Council, which is a national organization for dairy farmers. The purpose of this program is to provide accurate 
information on what dairy farms do to enable the public to understand the roles dairy farming play in the society. The aim of EDFs is not only to promote an open-door policy of the farmyard to the outside but also to enhance the educational value of dairy farming through teaching where milk comes from and showing the life of milk cows on the farm. For instance, when visitors have a milking experience, they learn that warm white milk comes out of the udder of the cow, which is a simple concept, but is quite different from the daily experience of drinking milk kept in a milk carton in the refrigerator. If visitors are lucky enough, they can see the birth of a calf, which makes a lifetime impression on children or even adults by evoking the meaning of life. People learn what food is and the close connection between food and life from these experiences. In this respect, a farmer's role is crucial and thus a farmer is called a facilitator in this program.

To be a facilitator for the EDFs, a farmer or a farm employee must attend a course on principles, safety, hygiene, and communication skills as well as a presentation of a case study provided by the Council. The Council administers certification for recognition as an Educational Dairy Farm and presents various capacity building courses for those with farms certified as an Educational Dairy Farm as well as dairy farmers at large in Japan. There were 257 EDFs as of 2009 when the survey was conducted.

Table 1 shows the trend of visitors to the EDFs. As can be easily recognized from the table, the number of visitors has increased yearly and reached nearly 880 thousand visitors in 2009 , which is a 3.89-fold increase from 2003. This increase was far more rapid than the increase in the number of EDFs, which was only 1.5-fold in the same period. The average number of visitors per farm increased from 1,353 to 3,421, a 2.53-fold increase. These facts suggest that the demand for farm experience has steadily grown to form a certain level of market or at least its potential. I assume that this mounting demand indicates a new social role that dairy farmers can play in the society, which are the educational function to consumers offered by these dairy farmers.

\section{DATA}

In keeping the analytical model on the cross identity effect in mind, first, the researcher employs an SFPF model to evaluate how factors related to the activity of the educational service that is connected with identity affect the technical efficiency of milk production, which is the main

Table 1: Trend of no. of visitors and no. of EDFs.

\begin{tabular}{llllllll}
\hline Year & $\begin{array}{l}\text { First period } \\
\text { (April- } \\
\text { September) }\end{array}$ & $\begin{array}{l}\text { Second } \\
\text { period } \\
\text { (October- } \\
\text { March) }\end{array}$ & $\begin{array}{l}\text { \% share } \\
\text { in first } \\
\text { period }\end{array}$ & Total & $\begin{array}{l}\text { Ratio for } \\
\text { each } \\
\text { year }\end{array}$ & $\begin{array}{l}\text { No. } \\
\text { EDFs }\end{array}$ & $\begin{array}{l}\text { No. } \\
\text { visitors } \\
\text { per farm }\end{array}$ \\
\hline 2003 & 162,484 & 63,392 & 71.9 & 225,876 & 1.00 & 167 & 1,353 \\
2004 & 254,542 & 89,600 & 74.0 & 344,142 & 1.52 & 174 & 1,978 \\
2005 & No data available & & & & 183 & \\
2006 & 421,855 & 133,285 & 76.0 & 555,140 & 2.46 & 200 & 2,776 \\
2007 & 465,593 & 225,114 & 67.4 & 690,707 & 3.06 & 217 & 3,183 \\
2008 & 473,220 & 232,348 & 67.1 & 705,568 & 3.12 & 249 & 2,834 \\
2009 & 662,629 & 216,600 & 75.4 & 879,229 & 3.89 & 257 & 3,421 \\
\hline
\end{tabular}

Source: Japan Dairy Council. 
activity of EDFs, unlike tourism ranches. Second, DEA is used for a simulation of how technical efficiency will vary when these farms maximize the two outputs by whether or not farmers levy charges for educational services. From these results, factors to be considered in designing support measures towards viable educational services will be discussed. Data were collected by a questionnaire survey to the entire group of 257 farms designated as EDFs by the Japan Dairy Council jointly conducted by the author and the Japan Dairy Council from October to December in 2009 by surface mail (response rate 79.4\%, 204 farms). The author conducted a supplementary survey by telephone. Sample size used for this study was 123 family farms to maintain homogeneity of the sample because there are various types of ranches designated as EDFs, such as publicly owned ranches, ranches run by educational institutions or cooperatives, etc., which are not necessarily oriented towards maximizing the profitability of milk production.

\section{EDUCATIONAL SERVICE AND PRICING}

Before the model estimation, let us provide an overview on the educational services that are actually offered by the EDFs according to the results of the questionnaire survey. Tables 2 and 3 indicate that these services can be classified into two types. One is a menu of individual activities that are separately offered such as milking, feeding cows, etc. The other is a set

Table 2: Offered educational dairy farm services (individual menu).

\begin{tabular}{lllllll}
\hline Type & Menu & $\begin{array}{l}\text { Service } \\
\text { provision }\end{array}$ & $\begin{array}{l}\text { Levying } \\
\text { service } \\
\text { charge }\end{array}$ & $\begin{array}{l}\text { Price of service (only } \\
\text { cases }\end{array}$ \\
\hline $\begin{array}{l}\text { Farmperation } \\
\text { experiences }\end{array}$ & \%ecture by farmer & \% farms & $\begin{array}{l}\text { Max. } \\
\text { price }\end{array}$ & $\begin{array}{l}\text { Min. } \\
\text { price }\end{array}$ & $\begin{array}{l}\text { Mean } \\
\text { price }\end{array}$ \\
& Milking & 93.7 & 33.1 & 2,000 & 250 & 590 \\
& Feeding & 77.8 & 56.9 & 1,500 & 300 & 681 \\
& Giving bottle to calves & 74.1 & 43.6 & 1,000 & 100 & 471 \\
& Cleaning barn & 58.2 & 26.1 & 500 & 300 & 433 \\
& Brushing animals & 48.7 & 33.9 & 530 & 200 & 404 \\
& Field work & 36.1 & 26.3 & 1,000 & 315 & 663 \\
& Tour of farmyard & 89.9 & 22.6 & 525 & 300 & 416 \\
\hline Food/rural & Horseback riding & 12.0 & 63.3 & 12,000 & 300 & 2,229 \\
cultural & Butter making & 62.7 & 75.8 & 1,000 & 200 & 503 \\
experiences & Cheese making & 17.7 & 75.1 & 5,000 & 200 & 983 \\
& Ice cream making & 23.4 & 73.1 & 1,500 & 400 & 712 \\
& Ham/sausage making & 3.8 & 100.0 & 5,000 & 500 & 1,938 \\
& Cutting sheep wool & 5.1 & 49.0 & 600 & 500 & 543 \\
\hline
\end{tabular}

Source: Questionnaire survey to the Educational Dairy Farms jointly conducted by the author and the Japan Dairy Council from October to December in 2009. Response rate was $79.4 \%$ (204/248). Only family farms (123 samples) were used for the evaluation. 
menu that is offered as a combination of several individual services. The individual menu is constituted of two kinds of services: experience of a regular dairy operation and cultural experience, such as making dairy food and horseback riding. Menu-wise, an on-site lecture by the farmer, milking, feeding cows, and giving a bottle to calves are the top four commonly provided services among the farm operation experiences. Percentages of farms that answered that they levied service charges were lower in this category than in the category of food and rural cultural experiences. In the case of rural cultural experiences, the cost of materials, e.g. milk and cream for butter making, has to be recovered, so that the percentage of farms levying a service charge and the price level are higher than when farm operation experiences are offered. Another interesting point is that both the percentage of those levying a service charge and the price of service for the set menu were much higher than for those having an individual menu (Table 3). Thus, it is safe to say that providing a set menu will be effective in raising the economic viability of educational services.

\section{VARIABLES FOR ESTIMATION}

First, as the input variables, the number of milk cows and acreage in feed production in 2009 were based on data from the survey mentioned above and supplemented by additional telephone interviews. Likewise, also based on the survey and telephone interview, the labour input variables were calibrated as real term labour input by taking into account the contribution of labour inputs for milk production and educational activity, respectively; full-time and main responsibility equals unity, fulltime and sub-responsibility equals 0.5 part-time and main responsibility 0.5 , and part-time sub-responsibility 0.25 .

As output data, the amount of annual milk production was used based also on the survey and supplementary telephone interview and data provided by the Japan Dairy Council for 2009. Basically the 2009 data were used. Nevertheless, data on 2009 production were missing for 23 farms although complete data for 2008 were available. The author confirmed with the local cooperatives that these farms with missing data were members of EDFs and confirmed that there were no major differences in the amount of milk produced between the two years, so the missing data for 2009 were replaced by 2008 data. To confirm this point statistically, I conducted a statistical $t$ test on the differences in reported milk production between 2008 and 2009, on milk production shown by 2009 data with substitutions using 2008 data and that with available 2009 data. Neither result showed any statistically significant differences, which enabled the use of 2009 data that were partially supplemented with 2008 data.

Table 3: Offered educational dairy farm services (set menu).

\begin{tabular}{llllll}
\hline Type & $\begin{array}{l}\text { Device } \\
\text { provision }\end{array}$ & $\begin{array}{l}\text { Levying } \\
\text { service charge }\end{array}$ & \multicolumn{2}{l}{ Price of service (only cases that charge): $¥$} \\
& \% farms & \% farms & Max. price & Min. price & Mean price \\
\hline Set menu 1 & 47.5 & 83.8 & 5,000 & 300 & 1,370 \\
Set menu 2 & 23.6 & 93.2 & 5,000 & 320 & 1,493 \\
Set menu 3 & 11.4 & 93.0 & 5,250 & 320 & 1,329 \\
Set menu 4 & 2.4 & 66.7 & 1,500 & 200 & 1,033 \\
Set menu 5 & 0.8 & 100.0 & 1,500 & 1,500 & 1,500 \\
\hline
\end{tabular}

Source: Same as Table 2. 
Table 4: Variables used for SFPF model estimation.

\begin{tabular}{llllll}
\hline Type & Variables & Mean & $\begin{array}{l}\text { Standard } \\
\text { Deviation }\end{array}$ & Min. value & Max. value \\
\hline Output & $\begin{array}{l}\text { Amount of milk production } \\
\text { in 2009 milk year (t) }\end{array}$ & 472.6 & 362.8 & 1.9 & $2,247.0$ \\
Input & $\begin{array}{l}\text { Labour input for milk } \\
\text { production (real term) }\end{array}$ & 3.07 & 1.83 & 0.50 & 13.50 \\
Input & No. milk cows & 93.0 & 68.8 & 8.0 & 450.0 \\
Input & $\begin{array}{l}\text { Acreage of feed production } \\
\text { (ha) }\end{array}$ & 21.8 & 24.9 & 0.1 & 160.0 \\
Inefficiency & $\begin{array}{l}\text { Coefficient of variance in } \\
\text { no. visitors in groups in } \\
\text { 2009 fiscal year }\end{array}$ & 1.61 & 0.72 & 0 & 2.65 \\
& & & & \\
\hline
\end{tabular}

Source: Table 2 and data on milk production and the number of visitors were obtained from the Japan Dairy Council.

Table 5: Dummy variables.

\begin{tabular}{llccc}
\hline Type & Variable & Yes & No & Total \\
\hline Inefficiency & Main person in charge of education & 49 & 74 & 123 \\
& services: female (yes=1, no=0) & $(39.8)$ & $(60.2)$ & $(100.0)$ \\
Inefficiency, & Leavying service charge & 59 & 64 & 123 \\
input & (yes=1, no=0) & $(48.0)$ & $(52.0)$ & $(100.0)$ \\
Inefficiency & Year of designation of EDF & 71 & 52 & 123 \\
& before 2004 (yes=1, no=0) & $(57.7)$ & $(42.3)$ & $(100.0)$ \\
\hline
\end{tabular}

Source: Same as in Table 2.

Note: Upper figure represents sample size and the lower figure in parentheses is $\%$.

Data used for estimation are summarized in Tables 4 and 5. The variables to evaluate the technical efficiency and identity effect were selected from the results of Chi-square test that showed statistical significance.

\section{EVALUATION OF THE IMPACT OF THE IDENTITY EFFECT ON THE EFFICIENCY OF MILK PRODUCTION}

As mentioned earlier, an emerging new activity like the educational service has not become a clear market good. This paper examines the cross identity effect, which is how the identityattributed factor of the educational activity affects the efficiency of the main activity, which is milk production. The SFPF that has technical and identity-attributed inefficiency factors is expressed for an educational dairy farm $i$ as below.

$$
Y i=f(n i, k i, l i) \exp (v j-u j)
$$

where, $y i=$ milk production of the farm $i, n i=$ labour input, $k i=$ capital input, $l i=$ land input, $v i=$ stochastic error, $u i=$ technical and identity inefficiency term. Here, suppose $y i^{*}$ as 
observable production, technical efficiency, TE, is defined as TE $=y i * / y i=\exp (-u i)$. The stochastic production function and technical inefficiency function are estimated simultaneously. Specifically, the Cobb-Douglas function was used. Labour and land inputs were as mentioned above and the number of milk cows was used for capital input. Because of data constraints on machinery and facility costs milk cows also constitute capital costs. To cope with this constraint, I assume that these capital costs of machinery and facilities are proportional to the number of milk cows. This assumption is also effective to avoid multicollinearity, which often causes a serious problem on the estimation of the production function. All three variables were transformed into a natural logarithm for estimation.

Regarding the impact of factors related to technical inefficiency in milk production, we need to consider conventional technical factors and the identity effect related to the educational services. It is highly probable as mentioned that the technical factors and the identity effect are mixed in reality, and it is also true that the degree of mixing is also different from one factor to another. It is assumed that these mixed technical and identity terms are stochastically distributed, similar to simple technical terms.

Variables to evaluate the technical efficiency and identity effect were selected from the results of Chi-square test that showed statistical significance. The first variable is the main person in charge of educational services: female (yes $=1$, no $=0$ ). This is to see the technical aspect of the educational service more than the identity effect. The second and third variables are related to the identity effect: levying a charge for the educational service (yes $=1$, no $=0$ ) and start of the educational dairy farm before 2004 (yes = 1, no =0). As mentioned earlier, it is considered that whether a farmer charges for educational services is determined by which identity the farmer has. The farmer's identity also is supposed to be reflected by the year that the educational service was launched, which represents the experience effect of the service and will raise the technical efficiency of the main production. The year 2004 is the midpoint between the start of the EDFs in 2000 and the survey year in 2009. As an optional variable, a coefficient of variance of the number of visitors in visitor groups in 2009 was used to see mainly a technical effect of fluctuations in terms of the number of visitors. There was no serious correlation among these variables. It is not possible, a priori, to judge which direction of influence these factors regarding the educational service exert on the main activity, but is an empirical question to be clarified by the estimation results.

\section{ESTIMATION RESULTS}

Table 6 shows the estimation results. Parameters of input variables, production elasticities, are all positive with statistical significance (1\% significance). Among the three parameters, the number of milk cows as capital input was largest while that of acreage in feed production as land input was the smallest. Since the hypothesis that the sum of the three production elasticities is unity was rejected by the Chi-square test, economy of scale existed in milk production.

Turning to parameters of the technical and identity effect, negative parameters mean that they increase efficiency while positive parameters indicate decreased efficiency. Now let us examine details of the results. First, the parameter of the female as the main educational service provider worked to increase the efficiency of milk production. This factor is considered to generate economy of scope by increasing efficiency in terms of labour allocation such as division of labour and better communication capability with visitors by female members as human resources, which resulted in enhancement of the comparative advantage of females in farm resource management. On the other hand, the parameter of the fluctuation of the number 
Table 6: Technical efficiency and inefficiency factors on milk production by EDF (SFPF).

\begin{tabular}{|c|c|c|}
\hline Model & 1 & 2 \\
\hline Explained variable & \multicolumn{2}{|c|}{ In (2009 milk production) } \\
\hline $\begin{array}{l}\text { Production elasticity } \\
\ln \text { (Labour input for milk production) }\end{array}$ & $\begin{array}{l}0.1442 * * * \\
(1.4 \mathrm{e}+04)\end{array}$ & $\begin{array}{l}0.1442 * * * \\
(1.9 \mathrm{e}+4)\end{array}$ \\
\hline In(No. milk cows) & $\begin{array}{l}0.9219 * * * \\
(2.5 \mathrm{e}+5)\end{array}$ & $\begin{array}{l}0.9219 * * * \\
(3.2 \mathrm{e}+05)\end{array}$ \\
\hline In(Acreage in feed production) & $\begin{array}{l}0.0703 * * * \\
(2.4 \mathrm{e}+04)\end{array}$ & $\begin{array}{l}0.0703 * * * \\
(3.0 \mathrm{e}+04)\end{array}$ \\
\hline Constant & $\begin{array}{l}2.2374 * * * \\
(1.9 \mathrm{e}+05)\end{array}$ & $\begin{array}{l}2.2374 * * * \\
(2.4 \mathrm{e}+05)\end{array}$ \\
\hline \multicolumn{3}{|l|}{ Technical and identity inefficiency factor } \\
\hline $\begin{array}{l}\text { Main person in charge of educational services: female } \\
(y e s=1, n o=0)\end{array}$ & $\begin{array}{l}-0.6932 * * * \\
(-2.60)\end{array}$ & $\begin{array}{l}-0.6126 * * \\
(-2.27)\end{array}$ \\
\hline Levying service charge $($ yes $=1$, no $=0$ ) & $\begin{array}{l}0.8602 * * * \\
(2.66)\end{array}$ & $\begin{array}{l}0.9359 * * * \\
(2.88)\end{array}$ \\
\hline Year of designation of EDF befopre 2004 (yes $=1$, no $=0$ ) & $\begin{array}{l}1.0730^{* * * *} \\
(3.25)\end{array}$ & $\begin{array}{l}1.0748^{* * *} \\
(3.24)\end{array}$ \\
\hline $\begin{array}{l}\text { Coefficient of variance of no. visitor in groups in } 2009 \\
\text { fiscal year }\end{array}$ & - & $\begin{array}{l}0.3092 * \\
(1.70)\end{array}$ \\
\hline Constant & $\begin{array}{l}-1.1932 * * * \\
(-5.42)\end{array}$ & $\begin{array}{l}-1.7831 * * * \\
(-4.61)\end{array}$ \\
\hline Sample size & 123 & 123 \\
\hline Wald Chi-square statistic & $3.26 \mathrm{e}+11 * * *$ & $4.78 \mathrm{e}+11 * * *$ \\
\hline Log likelihood & $-62.3704 * * *$ & $-61.0495 * * *$ \\
\hline (sum of production elasticity $\Phi=1$ ) & $5.1 \mathrm{e}+08 * * *$ & $8.7 \mathrm{e}+08 * * *$ \\
\hline Chi-square test & $\Phi>1$ & $\Phi>1$ \\
\hline
\end{tabular}

Source: Same as Table 4.

Notes: Figure in parentheses is $\mathrm{Z}$ value.***,**,*,indicate $1 \%, 5 \%, 10 \%$ significance.

of visitors per group was negative on the efficiency of milk production, probably because of intensifying competition among resource allocations.

Parameters of levying a service fee and an earlier launching year of the educational activity lowered the efficiency of milk production. This result, however, is hard to explain from technical aspects because the launching year represents the experience effect of the educational services, which would raise efficiency. There was no multicollinearity among the variables. Therefore, we need to consider the existence of the identity effect, which suggests that those 
levying a service charge are oriented towards the realization of maximize the overall managerial efficiency, including the educational services, rather than seeking efficient management of the single sector of milk production. If so, the technical efficiency of the main activity might be overestimated because the observed technical efficiency necessarily includes the identity effect in the case of farms with diversified activities. These results suggest that diversified farm operators have different behavioural principle from simple milk-producing farmers, so that further study is needed to verify this point fully.

\section{DISCUSSION AND CONCLUSION}

This paper investigated how farmer's identity influences managerial efficiency in emerging diversified farm activity by focusing on EDFs. Main points clarified in the paper are as follows:

1. This paper considers the identity effect, which means that resource management differs according to differences in farmers' identities. Based on consideration of the relationship between a farmer's identity and diversified activity, it was disclosed that in the case of diversified activity technical efficiency will be overestimated if the identity effect is not taken into account.

2. In empirically testing the identity effect, the estimation result of the SFPF for milk production indicated that the efficiency of those farms that levied charges for educational services was inferior to non-levying farms. Whether a service charge was levied was used as a practical indicator of farmers' orientation towards viable educational services and reflected the farmer's identity with regard to the educational service. This is probably because their aim of managerial efficiency is not solely placed on the maximization of milk production, but on farm resource management of the whole array of activities including milk production and the educational service.

3. In this respect, it is interesting to find that having females in charge of the educational services is favourable towards technical efficiency in milk production from the result of the SFPF. Therefore, it will become important to expand the activity domain for females in family farms not only in milk production, but also in educational service activities.

4. Consequently, it will be important to take into account what identity a farmer has towards farm diversification for designing policies for better support measures especially in the field of capability building in farm resource management in multiple sectors including educational tourism activity. Further empirical investigation is necessary to evaluate how farm operators maximize their overall managerial efficiency including educational tourism activity.

\section{ACKNOWLEDGEMENT}

This study was funded by the Japan Dairy Council and Grants-in-Aid for Scientific Research, No.16K14996, No. 24658191 and No. 26283017, Japan Society for the Promotion of science (JSPS).

\section{REFERENCES}

[1] Akerlof, G.A. \& Kranton, R.E., Identity Economics: How Our Identities Shape Our Work, Wages, and Well-being, Princeton University Press: Princeton, 2010. http://dx.doi.org/10.1515/9781400834181 
[2] Akerlof, G.A. \& Kranton, R.E., Economics and identity. The Quarterly Journal of Economics, 115(3), pp. 715-753, 2000.

http://dx.doi.org/10.1162/003355300554881

[3] Akerlof, G.A. \& Kranton, R.E., Identity and schooling: some lessons for the economics of education. Journal of Economic Literature, 40(49), pp. 1167-1201, 2002. http://dx.doi.org/10.1257/.40.4.1167

[4] Akerlof, G.A., The missing motivation in macroeconomics. The American Economic Review, 97(1), pp. 3-36, 2007. http://dx.doi.org/10.1257/aer.97.1.5

[5] Sen, A., Rational fools: a critique of the behavioral foundations of economic theory. Philosophy \& Public Affairs, 6(4), pp. 317-344, 1977.

[6] Sen, A., Goals, commitment, and identity. Journal of Law Economics and Organization, 1(2), pp. 341-355, 1985.

[7] Sen, A., Identity and Violence: The Illusion of Destiny, W.W. Norton and Co: New York, 2006.

[8] Bowles, S., The cultural consequences of markets and other economic institutions. Journal of Economic Literature, 36(1), pp. 75-111, 1998.

[9] Coelli, T.J., Rao, D.S.P., O’Donnell, C.J. \& Battese, G.E., An Introduction to Efficiency and Productivity Analysis, 2nd Edn, Springer: New York, 2005.

[10] Aigner, D.J., Lovell, C.A.K. \& Schmidt, P., Formulation and estimation of stochastic frontier production function models. Journal of Econometrics, 6, pp. 21-37, 1977. http://dx.doi.org/10.1016/0304-4076(77)90052-5

[11] Anderson, R.I., Fish, M., Xia, Y. \& Michello, F., Measuring efficiency in the hotel industry: a stochastic frontier approach. Hospitality Management, 18, pp. 45-57, 1999. http://dx.doi.org/10.1016/S0278-4319(98)00046-2

[12] Gragasin, M., Maruyama, A., Marciano, E., Fujiie, M. \& Kikuchi, M., Irrigators' association and farm productivity: a comparative study of two Philippine irrigation systems. Japanese Journal of Rural Economics, 7, pp. 1-17, 2005. http://dx.doi.org/10.18480/jjre.7.1

[13] Assaf, A.G., Barros, C.P. \& Machado, L.P., The future outlook for Portuguese travel agents. Tourism Economics, 17(2), pp. 405-423, 2011. http://dx.doi.org/10.5367/te.2011.0034

[14] Adhikari, C.B. \& Bjorndal, T., Analyses of technical efficiency using SDF and DEA models: evidence from Nepalese agriculture. Applied Economics, 44(25), pp. 32973308, 2012.

http://dx.doi.org/10.1080/00036846.2011.572856

[15] Ohe, Y., Evaluating internalization of multifunctionality by farm diversification: evidence from educational dairy farms in Japan. Journal of Environmental Management, 92(3), pp. 886-891, 2011. http://dx.doi.org/10.1016/j.jenvman.2010.10.048

[16] Ohe, Y., Emerging environmental and educational service of dairy farming in Japan: dilemma or opportunity? Ecosystems and Sustainable Development VI, eds. E. Tiezzi, J.C. Marques, C.A. Brebbia \& S.E. Jørgensen, WIT Press: Southampton, pp. 425-436, 2007.

[17] Ohe, Y., Evaluating operators' attitudes to educational tourism in dairy farms: the case of Japan. Tourism Economics, 18(3), pp. 577-595, 2012.

http://dx.doi.org/10.5367/te.2012.0131 